\title{
Radar surveys of the Rutford Ice Stream onset zone, West Antarctica: indications of flow (in)stability?
}

\author{
John WOODWARD, ${ }^{1}$ Edward C. $\mathrm{KING}^{2}$ \\ ${ }^{1}$ School of Applied Sciences, Northumbria University, Ellison Place, Newcastle upon Tyne NE1 8ST, UK \\ E-mail: john.woodward@northumbria.ac.uk \\ ${ }^{2}$ Physical Sciences Division, British Antarctic Survey, Natural Environment Research Council, Madingley Road, \\ Cambridge CB3 OET, UK
}

\begin{abstract}
We present 1 and $100 \mathrm{MHz}$ ground-based radar data from the onset region of Rutford Ice Stream, West Antarctica, which indicate the form and internal structure of isochrones. In the flowparallel lines, modelled isochrone patterns reproduce the gross pattern of the imaged near-surface layers, assuming steady-state flow velocity from GPS records and the current accumulation rate for the last 200 years. We interpret this as indicating overall stability in flow in the onset region of Rutford Ice Stream throughout this period. However, in the cross-flow lines some local variability in accumulation is seen in areas close to the ice-stream margin where a number of tributaries converge towards the icestream onset zone. Episodic surface lowering events are observed followed by rapid fill episodes. The fill events indicate deposition towards the northwest, most likely generated by storm winds, which blow at an oblique angle to ice flow. More problematic is explaining the generation of episodic surface lowering in this area. We speculate this may be due to: changing ice-flow direction in the complex tributary area of the onset zone; a change in basal sediments or sedimentary landforms; a change in basal melt rates or water supply; or episodic lake drainage events in the fjord systems of the Ellsworth Subglacial Highlands. The study highlights the difficulty of assessing flow stability in the complex onset regions of West Antarctic ice streams.
\end{abstract}

\section{INTRODUCTION}

Ice streams are a dynamic component of the West Antarctic ice sheet (WAIS) system, draining as much as $90 \%$ of the Antarctic ice sheet (Morgan and others, 1982). It is likely that ice streams will be sensitive to changes in the ice sheet, climate and sea level and may be the regions of the WAIS where the effects of any change may be first observed. In attempts to identify forcing on the system, recent studies have concentrated on the ice-stream/ice-shelf interface, suggesting that grounding-line migration may indicate (in)stability (e.g. Budd and others, 1984; McInnes and Budd, 1984; Anandakrishnan and others, 2007). Another zone of potentially significant change is the ice-stream onset region. Here the ice-flow speed increases rapidly, from typical slowmoving inland ice-sheet velocities (possibly dominated by deformation within the ice column) to those speeds characteristic of an active ice stream (with an increased degree of basal sliding and/or sediment deformation at the base). An outstanding question is, how stable are these zones of onset? Two components play a role in this stability: (1) glacier flow dynamics and (2) surface accumulation patterns. Rapid change in flow dynamics may be controlled by changes in the subglacial hydrological and/or subglacial sediment regime. Sudden and pronounced changes in accumulation may be generated by changing patterns of precipitation, as well as redistribution of snowfall due to wind scour and transport.

Radar profiles on ice sheets commonly reveal change in flow regime or the patterns of accumulation through examination of isochrones identified from radar reflections (Richardson and others, 1997; Vaughan and others, 2004). These layers are believed to be generated from density (Robin and others, 1969) and chemical differences in the ice and firn (e.g. Paren and Robin, 1975). This study aims to assess recent stability, in terms of flow velocity and accumulation, at the onset region of Rutford Ice Stream, West Antarctica, from analysis of internal isochrones in ground-penetrating radar (GPR) and Deep-Look Radio Echo Sounder (DELORES) profiles.

\section{FIELD SITE}

Rutford Ice Stream drains a catchment area of the WAIS from the Ellsworth Mountains, flowing into the southwest corner of the Filchner-Ronne Ice Shelf (Fig. 1). In the upstream area of the ice stream, known as the onset region, flow accelerates from 65 to $110 \mathrm{~m} \mathrm{a}^{-1}$ (King and others, 2004). The survey is centred on $76^{\circ} 54^{\prime} 59^{\prime \prime} \mathrm{S}, 88^{\circ} 06^{\prime} 18^{\prime \prime} \mathrm{W}$ at a zone of convergence where flow is channelled from a wide catchment basin above the Ellsworth Mountains into the head of the ice stream. Downstream of the onset region the ice-stream margins are largely topographically controlled, with a deep trough running south between the Ellsworth Mountains and Fletcher Promontory. Snow accumulation data from a site $40 \mathrm{~km}$ to the west show that accumulation rates have varied between 0.34 and $0.39 \mathrm{~m} \mathrm{a}^{-1}$ w.e. over the period 1780-2001 (Kaspari and others, 2004).

\section{METHODOLOGY}

\subsection{Ground-penetrating radar (GPR)}

Approximately $66 \mathrm{~km}$ of $100 \mathrm{MHz}$ pulseEKKO GPR profiles were collected in the onset region of Rutford Ice Stream during austral summer 2002/03. Profiles were collected in continuous mode and comprised a $26 \mathrm{~km}$ long line parallel to flow, together with a $40 \mathrm{~km}$ transverse line (Fig. 1). 


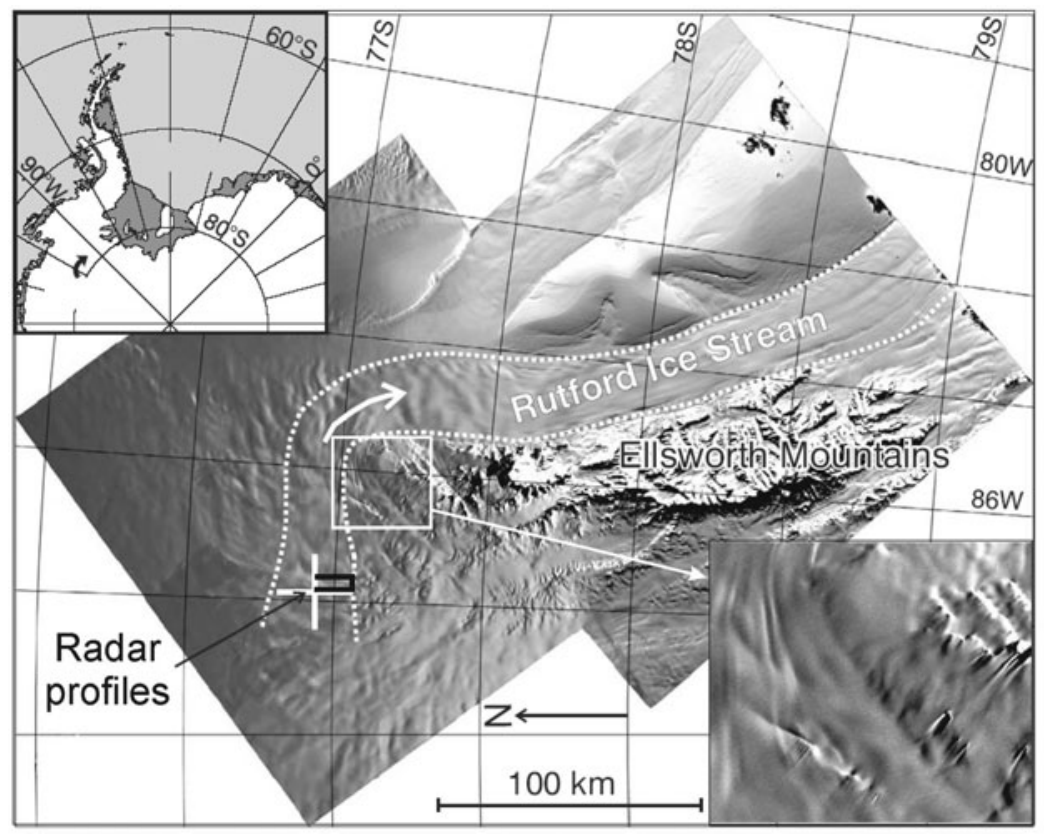

Fig. 1. Location of Rutford Ice Stream, West Antarctica, showing the location of GPR lines (white lines) and DELORES profiles (black lines). Inset magnification of moderate-resolution imaging spectroradiometer (MODIS) image shows the direction of wind tails (southeastnorthwest) generated by storm conditions behind nunataks at the northwestern end of the Ellsworth Mountains.

Processing involved drift correction, time zero correction, dewow and bandpass filtering, background removal and application of a time-varying automatic gain. A value for radar wave speed of $0.194 \mathrm{mns}^{-1}$ was applied for depth corrections, following common-midpoint (CMP) calculations by Nath and Vaughan (2003) for GPR data on Rutford Ice Stream at a similar elevation. This average will underestimate near-surface depths and very slightly overestimate the depth of deeper layers.

\subsection{Deep-look radar (DELORES)}

Over $45 \mathrm{~km}$ of deep-look radar data were acquired with the British Antarctic Survey's DELORES system during austral

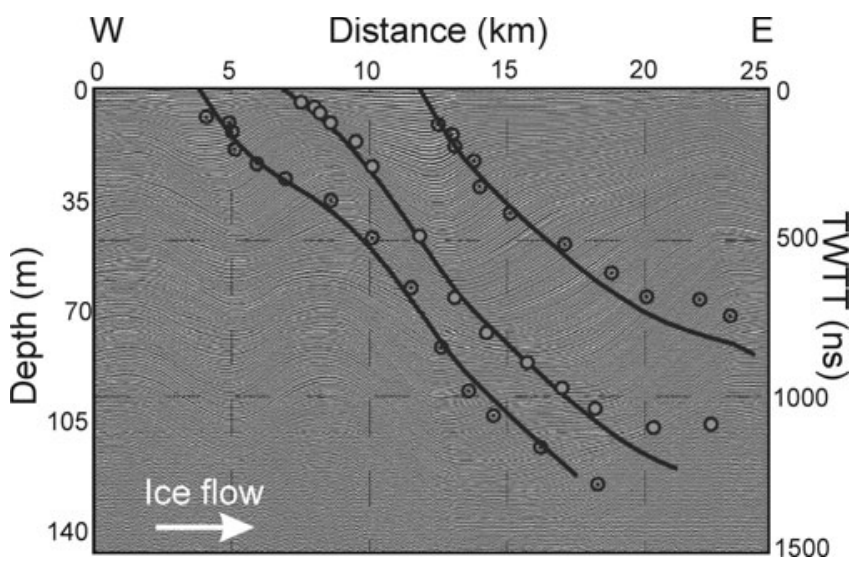

Fig. 2. GPR long profile running down the centre line of the ice stream. The wave-like pattern reflects accumulation differences linked to surface elevation. Modelled particle paths originating at the accumulation maxima at 4 and $12 \mathrm{~km}$ and the accumulation minimum at $7 \mathrm{~km}$ are plotted as solid lines. Open circles mark the maximum two-way travel-time (TWTT) difference between pairs of isochrones, and closed circles mark the minimum difference. See text for full explanation of the model. summer 2004/05. DELORES is a monopulse radar capable of operating between 1 and $20 \mathrm{MHz}$. The transmitter comprised a Kentech pulse generator that produced $\pm 2000 \mathrm{~V}$ pulses at a repetition rate of $1-5 \mathrm{kHz}$. The data presented here were acquired with dipole antennae of $40 \mathrm{~m}$ length that have a peak frequency of $1 \mathrm{MHz}$. The receiving system comprised an identical antenna pair coupled to a digital oscilloscope via a balun and amplifier. Three thousand pulses were stacked for each trace. Processing involved bandpass filtering, a gain function, a twodimensional (2-D) median filter to remove noise spikes and Kirchhoff migration. We used a constant wave speed of $0.167 \mathrm{~m} \mathrm{~ns}^{-1}$ for migration and depth conversion. This speed is optimal for migration of diffractions from the bed and for correcting the slope of deeper layers but is not optimal for migration in the shallower section. No CMP information is available to provide guidance on a 2-D velocity model, so we have elected to use a constant wave speed throughout the record.

\section{RADAR RESULTS}

\subsection{GPR profiles}

The GPR profiles display a set of internal reflectors to a depth of up to $150 \mathrm{~m}$ (Fig. 2). Reflections indicate that:

The pattern of near-surface reflections is controlled by accumulation, which appears to be controlled mainly by surface topography. Some layers are continuous and can be traced throughout the $26 \mathrm{~km}$ length of the flowparallel profile. The reflections are further apart on upstream-facing slopes than on downstream-facing slopes. In places (e.g. between 9 and $12 \mathrm{~km}$ on the along-flow line (Fig. 2)), some reflections on the downstream-facing slopes are difficult to trace, and lose coherence, as the layer thickness drops below the resolution of the GPR. 

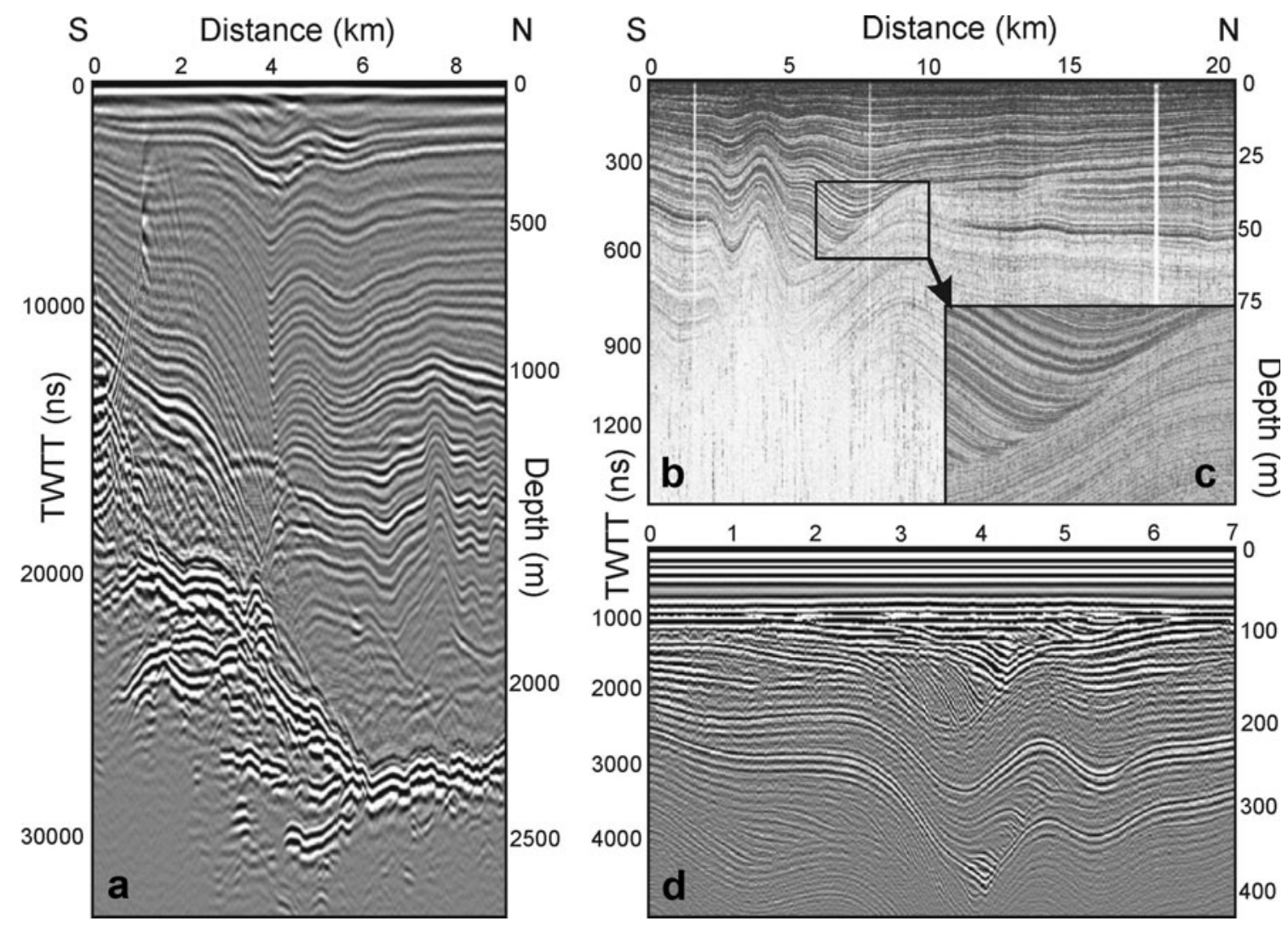

Fig. 3. GPR and DELORES images of the infill feature near the southern margin of the ice stream. (a) $1 \mathrm{MHz}$ DELORES data showing a rapid change in basal topography from $1000 \mathrm{~m}$ depth at the southern end of the profile, with a steep slope to the ice-stream bed at $>2200 \mathrm{~m}$ to the north of the line. At the near surface a reflection anomaly can be seen between 2.8 and $6 \mathrm{~km}$. (b) GPR line showing a near-surface fill structure between 5 and $10 \mathrm{~km}$. The inset (c) shows the reflections onlapping from south to north. (d) DELORES data bandpassed between 10 and $20 \mathrm{MHz}$. A series of infill packages spanning $>400$ years of accumulation shows a periodic nature to the infill phases. Foresets dip from south to north.

Areas of high accumulation on the upstream slopes generate trough-like structures that propagate through the depth of the GPR profile.

From 10 to $40 \mathrm{~km}$ on the cross-flow line, reflections can be traced throughout the GPR profile and are nearparallel to the surface.

Between 2 and $10 \mathrm{~km}$ on the cross-flow line, there is a change in the reflection pattern (Fig. 3b). Zones of infill are apparent, with 'foreset' layers filling hollows in the profile from the southern edge of the profile (Fig. 3c).

\subsection{DELORES profiles}

The flow-parallel and perpendicular DELORES surveys in the same area reveal internal layering to the bed of the ice stream at $\sim 2200 \mathrm{~m}$ depth (Figs 3 and 4 ). Reflections indicate that:

The zone of infill structures lies directly above a series of steps in bedrock topography (associated with the icestream margin). Ice thickness increases from $\sim 1500 \mathrm{~m}$ to $>2200 \mathrm{~m}$. This also creates a trough in the surface topography.

There are a series of infill structures between prominent reflection horizons that extend for considerable spatial distances (Fig. 4).
The flow-parallel and perpendicular DELORES lines indicate that the infill patterns resemble foresets deposited from a southeasterly direction.

The trough in which the foresets are deposited follows a basal low, channelling ice flow into the main flow of the ice stream.

\section{INTERPRETATION AND DISCUSSION}

\subsection{Long-profile isochrone pattern}

GPR profiles reveal a series of near-surface layers to depths of $\sim 150 \mathrm{~m}$. DELORES surveys along the same transects reveal internal layering to the bed of the ice stream at $\sim 2200 \mathrm{~m}$ depth. We interpret this layering as representing annual depositional isochrones (following Richardson and others, 1997; Vaughan and others, 2004). Relative accumulation along the profile has been estimated by tracing an annual near-surface layer (isochrone), giving a baseline accumulation of $0.43 \pm 0.02 \mathrm{~m}$ w.e. $\mathrm{a}^{-1}$. Assuming accumulation over the last 200 years has remained constant, the development of firn layers can be predicted in an along-flow direction following the methods of L. Gray and others (http://neptune.gsfc.nasa.gov/wais/pastmeetings/PPT05/ Gray.ppt):

$$
V=V_{\mathrm{i}}+k x,
$$

where $V$ is the downstream velocity variation, $V_{\mathrm{i}}$ is initial 


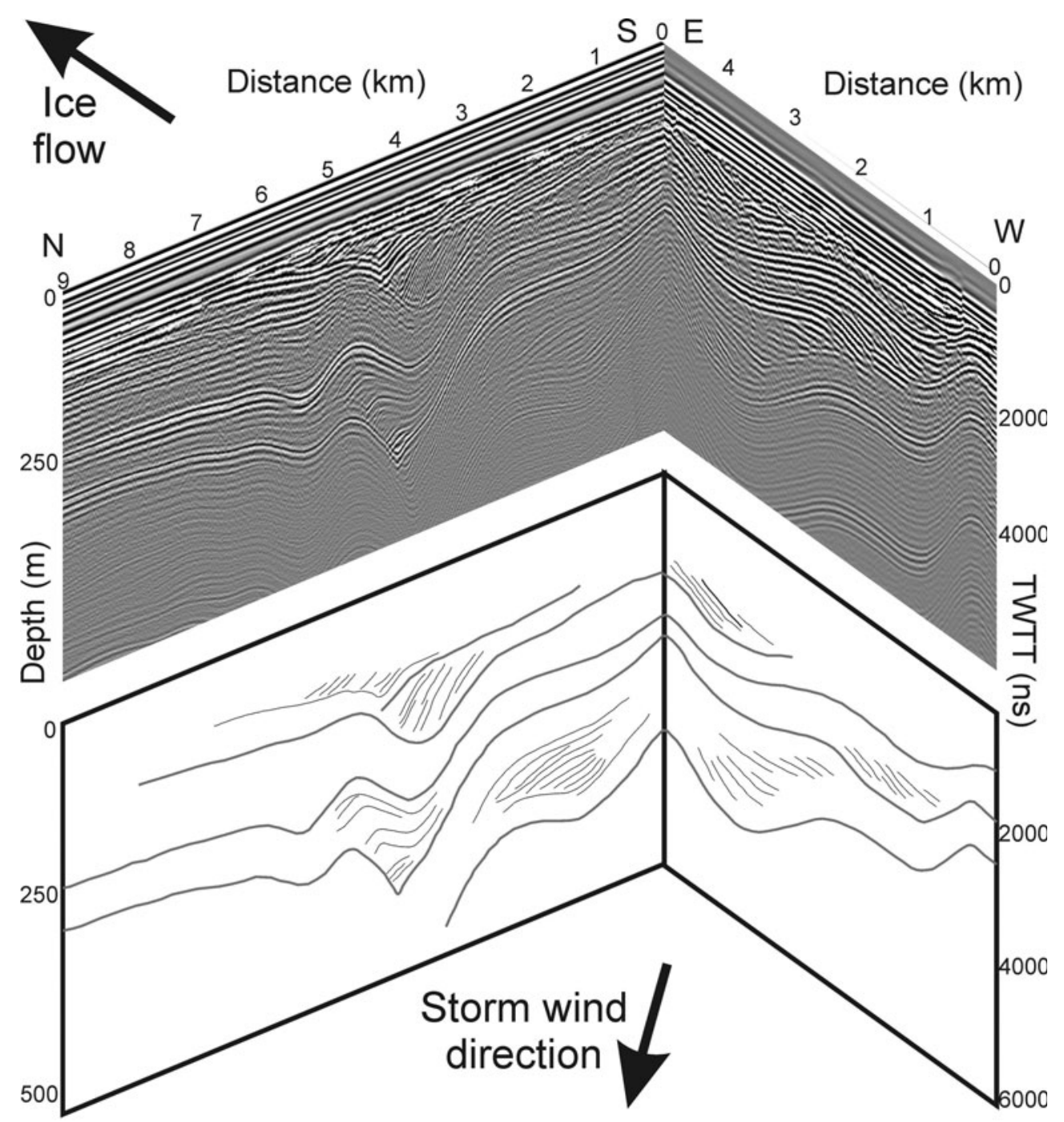

Fig. 4. Two perpendicular DELORES lines showing a series of infill structures between prominent reflection horizons. The infill patterns resemble foresets deposited from a southeasterly direction, the dominant direction of storm winds.

velocity, and $k$ is the longitudinal strain rate that is a function of $x$, the position along the flowline. Velocity along the GPR profile is known from global positioning system (GPS) measurements that show flow acceleration from 65 to $110 \mathrm{~m} \mathrm{a}^{-1}$ along the profile. Assuming that close to the centre of the ice stream the transverse strain rate is zero, a $1 \mathrm{~m}$ distance across-flow stays as $1 \mathrm{~m}$, so the simulation is two-dimensional (along-flow and vertical). After time $t$ years a point in the firn will have travelled a distance $x$ :

$$
x=\frac{V_{\mathrm{i}}}{k}[\exp (k t)-1] \text {. }
$$

After $t$ years, an along-flow distance of $1 \mathrm{~m}$ becomes $d$, where:

$$
d=\exp (k t)
$$

With conservation of material the layer thickness $L$ is then

$$
L=\exp (-k t) \text {. }
$$

The layer thickness reduces progressively with depth due to compaction, therefore $L$ was scaled according to the density-depth relationship of Herron and Langway (1980). Finally, the permittivity-density relationship of Kovacs and others (1995) was used to convert the modelled layer structure to radar two-way travel time to allow plotting on the GPR profile. Particle paths originating at three locations were calculated for the last 200 years, plotted as solid lines in Figure 2. The origin points are the two accumulation maxima at 4 and $12 \mathrm{~km}$ and the accumulation minimum at $7 \mathrm{~km}$. The end-points of the particle path lines would ideally all coincide with one isochrone on the GPR profile. The degree to which they do not gives a measure of the error of the method. In order to trace the accumulation maxima and minima down the record, we determined the travel time difference between pairs of isochrones and plotted the maximum difference as open circles, and the minimum difference as filled circles, in Figure 2. The close correspondence between modelled particle paths and the locus of the accumulation maxima and minima suggests that the assumption of constant flow velocity and constant accumulation pattern for the time period is valid. The fit is not as good as for other data, such as those collected on Bindschadler Ice Stream (L. Gray and others, http:// neptune.gsfc.nasa.gov/wais/pastmeetings/PPT05/Gray.ppt). This is most likely due to errors in the velocity profile propagating through into longitudinal strain-rate variations or errors in the accumulation estimates. For most of the 
cross-flow line, isochrones appear continuous and nearparallel to the surface. We interpret the modelling results as indicating approximate steady-state flow conditions in the central part of the ice-stream onset zone for the last 200 years.

\subsection{Anomalous fill patterns near ice-stream margin}

Between 2 and $10 \mathrm{~km}$ on the GPR cross-flow line, there are a series of depressions in the isochrone pattern (Fig. $3 \mathrm{~b}$ and c). The surface depressions appear to be generated by localized, episodic surface deflation rather than surface erosional events, as isochrones are not cross-cut. The DELORES data show similar, multiple zones of downwarped isochrones with foresets filling the hollows from the southern edge of the profile (Fig. 3a and d). The isochrone pattern suggests surface depressions have been generated and then infilled on a number of occasions (Fig. 4). Current steady-state accumulation is dominated by katabatic winds that blow eastwards at the study site, approximately parallel to the icestream flow. The fill structures have instead been deposited by storm winds blowing northwestwards, at an oblique angle to ice flow (Fig. 1). Form similar features seen in sandy braided river systems (Best and others, 2006) are generated from flow depositing sands as foresets into previously scoured bar-top hollows. This indicates that the infill events can be generated by snow redeposition from storm winds under normal cyclonic patterns.

Siegert and others (2004a) suggest that distorted internal layers can be produced by at least six processes, including changing basal topography, strain-rate variations, changes in surface accumulation, converging or diverging ice flow, changing basal flow conditions and basal melting. Considering these processes, it seems most likely that episodic surface depression in this area of the onset zone could be generated by:

A change in flow patterns: The basal topography is complex, as this margin of the onset zone is above the Ellsworth Subglacial Highlands. Changes in surface elevation or accumulation patterns could result in flow switching around subglacial highs, possibly episodically altering flow into the ice stream at this location.

Change in basal sediments or sedimentary landforms: Seismic and radar surveys in the centre of the ice stream indicate that basal sediments are important for accelerating flow in the onset region, with dilatant sediments being deformed into drumlinoid land systems at the icestream bed (King and others, 2007). Any temporal or spatial variations in sediment conditions or sediment supply could result in differential flow and possible folding of internal layers.

Change in basal melting or water supply: Seismic surveys in the ice-stream centre also suggest that water may be important for generating fast flow in the onset region (King and others, 2004). Changes in the volume of water supplied due to reduced (or enhanced) basal melt or water piracy in the complex basal topography around the Ellsworth Subglacial Highlands could result in reduced (or enhanced) flow in a tributary.

Subglacial lake drainage: The Ellsworth Subglacial Highlands are known to contain a series of subglacial lakes in topographically controlled, fjord-like environments (Siegert and others, 2004b; Vaughan and others,
2007). Drainage mechanisms for these lakes are currently poorly constrained, though other lakes in Antarctica are now known to drain episodically (Gray and others, 2005; Wingham and others, 2006; Fricker and others, 2007). Such episodic events would create downwarping in the internal layers and a surface topographic low that could then be infilled.

These preliminary and somewhat speculative observations indicate that onset zones, particularly those located over subglacial highland regions, can have a high degree of internal instability and complexity. Further data collection and modelling are required to assess the stability of the regions of onset of fast flow within the complex flow patterns of the WAIS.

\section{CONCLUSIONS}

This study combines near-surface GPR and deep-look DELORES radar data, enabling internal layers to be traced from the surface to a substantial depth in the onset zone of Rutford Ice Stream. Modelled particle paths, assuming steady-state velocity and accumulation, reproduce flowparallel particle paths interpreted from the GPR. This evidence suggests that the flow regime in the centre of the onset region has remained relatively constant for the last 200 years. However, in the cross-flow lines some local variability in accumulation is seen in areas close to the icestream margin where episodic fill structures are observed as foreset depositional features. This deposition indicates episodic change in a tributary, most likely from changing basal conditions, in order to periodically develop a surface depression that is then infilled. The study indicates the difficulty of assessing stability in onset zones. Further work is required to assess controls on flow in the tributaries converging from the Ellsworth Subglacial Highlands into the onset zone of Rutford Ice Stream.

\section{ACKNOWLEDGEMENTS}

We thank L. Gray for assistance with the modelling, particularly the work behind Figure 2. We acknowledge the field support provided by C. Bailey, J. Bursnall, G. Middleton and C. Griffiths, together with the operations staff of Rothera Research Station. H. Conway and an anonymous reviewer provided invaluable comments that have led to reinterpretation of the dataset and improvement of this paper

\section{REFERENCES}

Anandakrishnan, S., G.A. Catania, R.B. Alley and H.J. Horgan. 2007. Discovery of till deposition at the grounding line of Whillans Ice Stream. Science, 315(5820), 1835-1838.

Best, J., J. Woodward, P. Ashworth, G.H. Sambrook Smith and C. Simpson. 2006. Bar-top hollows: a new element in the architecture of sandy braided rivers. Sediment. Geol., 190(1), 241-255.

Budd, W.F., D. Jenssen and I.N. Smith. 1984. A three-dimensional time-dependent model of the West Antarctic ice sheet. Ann. Glaciol., 5, 29-36.

Fricker, H.A., T. Scambos, R. Bindschadler and L. Padman. 2007. An active subglacial water system in West Antarctica mapped from space. Science, 315(5818), 1544-1548.

Gray, L., I. Joughin, S. Tulaczyk, V.B. Spikes, R. Bindschadler and K. Jezek. 2005. Evidence for subglacial water transport in the West Antarctic Ice Sheet through three-dimensional satellite 
radar interferometry. Geophys. Res. Lett., 32(3), L03501. (10.1029/2004GL021387.)

Herron, M.M. and C.C. Langway, Jr. 1980. Firn densification: an empirical model. J. Glaciol., 25(93), 373-385.

Kaspari, S. and 6 others. 2004. Climate variability in West Antarctica derived from annual accumulation-rate records from ITASE firn/ice cores. Ann. Glaciol., 39, 585-594.

King, E.C., J.M. Woodward and A.M. Smith. 2004. Seismic evidence for a water-filled canal in deforming till beneath Rutford Ice Stream, West Antarctica. Geophys. Res. Lett., 31(20), L20401. (10.1029/2004GL020379.)

King, E.C., J. Woodward and A.M. Smith. 2007. Seismic and radar observations of subglacial bed forms beneath the onset zone of Rutford Ice Stream, Antarctica. J. Glaciol., 53(183), $665-672$.

Kovacs, A., A.J. Gow and R. Morey. 1995. A reassessment of the insitu dielectric constant of polar firn. CRREL Rep. 93-26.

McInnes, B.J. and W.F. Budd. 1984. A cross-sectional model for West Antarctica. Ann. Glaciol., 5, 95-99.

Morgan, V.I., T.H. Jacka, G.J. Akerman and A.L. Clarke. 1982. Outlet glacier and mass-budget studies in Enderby, Kemp and Mac. Robertson lands, Antarctica. Ann. Glaciol., 3, 204-210.

Nath, P.C. and D.G. Vaughan. 2003. Subsurface crevasse formation in glaciers and ice sheets. J. Geophys. Res., 108(B1), 2020. (10.1029/2001JB000453.)
Paren, J.G. and G.de Q. Robin. 1975. Internal reflections in polar ice sheets. J. Glaciol., 14(71), 251-259.

Richardson, C., E. Aarholt, S.E. Hamran, P. Holmlund and E. Isaksson. 1997. Spatial distribution of snow in western Dronning Maud Land, East Antarctica, mapped by a groundbased snow radar. J. Geophys. Res., 102(B9), 20,343-20,353.

Robin, G.de Q., S. Evans and J.T. Bailey. 1969. Interpretation of radio echo sounding in polar ice sheets. Philos. Trans. $R$. Soc. London, Ser. A, 265(1166), 437-505.

Siegert, M.J. and 9 others. 2004a. Ice flow direction change in Interior West Antarctica. Science, 305(5692), 1948-1951.

Siegert, M.J. and 7 others. 2004b. Subglacial Lake Ellsworth: a candidate for in situ exploration in West Antarctica. Geophys. Res. Lett., 31(23), L23403. (10.1029/2004GL021477.)

Vaughan, D.G., P.S. Anderson, J.C. King, G.W. Mann, S.D. Mobbs and R.S. Ladkin. 2004. Imaging of firn isochrones across an Antarctic ice rise and implications for patterns of snow accumulation rate. J. Glaciol., 50(170), 413-418.

Vaughan, D.G., A. Rivera, J. Woodward, H. Corr, J. Wendt and R. Zamora. 2007. Topographic and hydrological controls on Subglacial Lake Ellsworth, West Antarctica. Geophys. Res. Lett., 34(18), L18501. (10.1029/2007GL030769.)

Wingham, D.J., M.J. Siegert, A. Shepherd and A.S. Muir. 2006. Rapid discharge connects Antarctic subglacial lakes. Nature, 440(7087), 1033-1036. 